\title{
DISCLAIMER
}

This report was prepared as an account of work sponsored by an agency of the United States Government. Neither the United States Government nor any agency thereof, nor any of their employees, makes any warranty, express or implied, or assumes any legal liability or responsibility for the accuracy, completeness, or usefulness of any information, apparatus, product, or process disclosed, or represents that its use would not infringe privately owned rights. Reference herein to any specific commercial product, process, or service by trade name, trademark, manufacturer, or otherwise does not necessarily constitute or imply its endorsement, recommendation, or favoring by the United States Government or any agency thereof. The views and opinions of authors expressed herein do not necessarily state or reflect those of the United States Government or any agency thereof.

\section{RCRA Designation of Discarded Americium/Beryllium Sealed Sources}

Nancy P. Kirner

September 1994

\section{Ebasco Environmental \\ Idaho Falls, ID 83404}

Prepared for EG\&G Idaho, Inc. Under Subcontract No. C90-132744

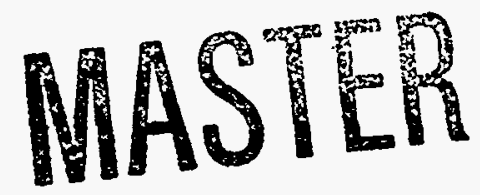

and for the

U.S. Department of Energy

Assistant Secretary for Environmental Management

Under DOE Idaho Operations Office

Contract DE-AC07-76ID01570 



\section{DISCLAIMER}

Portions of this document may be illegible in electronic image products. Images are produced from the best available original document. 


\begin{abstract}
Many sealed sources containing americium and beryllium are used throughout construction, industry, and research, and will eventually require disposal. For planning purposes it is necessary to determine whether these sources, when disposed, constitute a mixed waste, i.e., a waste containing hazardous constituents regulated under the Resource Conservation and Recovery Act and radioactive constituents regulated under the Atomic Energy Act.

Waste designation criteria contained in 40 CFR 261 are evaluated in detail in this report. It is determined that discarded americium/beryllium sealed sources do not contain any wastes listed in Subpart D of 40 CFR 261 , nor do the discarded sources exhibit any hazardous characteristics. Therefore, it is concluded that discarded americium/beryllium sealed sources are not a mixed waste under regulations established by the U.S. Environmental Protection Agency. Hazardous waste regulatory programs delegated to States, however, may have regulations that differ from those of the Federal government.
\end{abstract}




\section{EXECUTIVE SUMMARY}

This report evaluates whether discarded sealed sources containing americium and beryllium are regulated as hazardous waste under the Resource Conservation and Recovery Act (RCRA), and concludes that such sources are not hazardous waste under RCRA. Telephone inquiries were conducted to determine whether major manufacturers and government agencies have reached a conclusion concerning this issue. Only one individual stated that his company had examined the question, and had determined that the discarded sources would not be mixed waste, but he did not state a reason for this conclusion. That company's determination has not been committed to writing.

The construction details and characteristics of americium/beryllium (AmBe) sealed sources selected for this designation were obtained using the U.S. Nuclear Regulatory Commission's Sealed Source and Device Catalogue. The vast majority of AmBe sources are manufactured by Amersham Corporation. AmBe sealed sources are most frequently used in moisture/density gauges, where the source strength is nominally $50 \mathrm{mCi}$. AmBe neutron sources are typically made from a mixture of ${ }^{241} \mathrm{Am}$ oxide (source powder) and beryllium oxide (target powder). These oxides are typically fine powders that are mixed and compressed into a pellet, and pressed into the inner capsule of a "sealed source." The mixing and compression is essential to produce sources with constant and high neutron yield.

The AmBe sealed sources for which the U.S. Department of Energy (DOE) has disposal responsibility under the Low-Level Radioactive Waste Policy Amendments Act of 1985 qualify as solid waste as defined in 40 CFR 261.2. Additionally, the gauge or device holding the sealed source is considered a solid waste unless it is performing a useful function such as shielding. If the sources are removed from the device to reduce the volume of waste requiring disposal, both the device and the sealed sources would constitute solid waste and require evaluation as hazardous waste under the following three tests:

1. Is the waste specifically excluded from regulation under 40 CFR 261.4 ?

2. Is the waste listed as a hazardous waste in Subpart D of 40 CFR Part 261?

3. Does the waste exhibit one or more of the characteristics identified in Subpart C of 40 CFR Part 261, either by testing or through process knowledge?

AmBe sources are not specifically excluded from regulation as hazardous waste under 40 CFR 261.4(b). To be a listed hazardous waste in Subpart D of 40 CFR 261, the waste must either be generated from nonspecific sources (F-listed wastes), specific sources (K-listed wastes), or be discarded commercial chemical products, off-specification species, container residues, or spill residues thereof ( $\mathrm{P}$ - or U-listed wastes). None of the $28 \mathrm{~F}$-listed wastes describes an $\mathrm{AmBe}$ source. Similarly, none of the $101 \mathrm{~K}$-listed wastes or the more than $400 \mathrm{U}$-listed wastes pertain to discarded AmBe sources.

The P-listed wastes identify "beryllium powder" as a P015 waste. However, the applicability of this P-listed waste code depends on the definition of the phrase "commercial 
chemical product or manufacturing chemical intermediate." According to 40 CFR 261.33(d), this phrase refers to a chemical substance which consists of the commercially pure grade of the chemical, any technical grades of the chemical that are produced or marketed, and all formulations in which the chemical is the sole active ingredient. The U.S. Environmental Protection Agency (EPA) established the P- and U-listed wastes to halt indiscriminate dumping of unused portions of chemicals during the manufacturing process. The AmBe sealed sources, however, are the result of a manufacturing process, and are intended for commercial use. The beryllium from these processes has become a manufactured article, and although it is intended for commercial or manufacturing use, it can no longer be considered a commercially pure grade of the chemical. Therefore, because AmBe sources are manufactured articles containing one of the chemicals listed in 40 CFR 261.33(e) and the sources are not specifically listed elsewhere, AmBe sources would not qualify as P-listed wastes.

Beryllium that is recovered and reused from recycled sealed sources also does not qualify for listing as a P-listed waste because it has not been discarded. However, any discarded beryllium residues/wastes from the recycling process would qualify as a P-listed waste.

Under RCRA regulations, characteristic wastes are those that are ignitable, corrosive, reactive, or toxic. Sealed sources composed of americium, beryllium, and stainless steel are not ignitable, corrosive, or reactive under the definition in 40 CFR 261.

Toxicity characteristic wastes are those that, when subjected to the specified Toxicity Characteristic Leaching Procedure (TCLP), produce a leachate that exceeds specified concentration levels for any of 40 chemicals listed in 40 CFR 261.24. While neither beryllium nor americium is listed as a toxicity characteristic contaminant, elements known to be present in stainless steel such as chromium and those present in solder such as silver are listed as toxicity characteristic contaminants. To definitively answer the question of whether AmBe sealed sources qualify as toxicity characteristic hazardous waste, TCLP tests were performed on samples of 304 stainless steel and silver solder. Low concentrations of chromium and silver were reported; data validation for these laboratory results confirmed that neither the silver value for the sample of silver solder nor the chromium value for the sample of stainless steel exceeded the TCLP regulatory limits specified in $40 \mathrm{CFR}$ 261.24. It can be concluded that AmBe sealed sources do not constitute a RCRA toxicity characteristic waste.

Whether the EPA will act to list neutron sources with beryllium targets as future F- or Klisted wastes involves factors well beyond DOE's control. However, barring a major accident involving an AmBe source, it is likely that the EPA will consider that the radiological controls for sealed sources would provide an ample margin of safety to control the toxic nature of beryllium. 


\section{CONTENTS}

ABSTRACT $\ldots \ldots \ldots \ldots \ldots \ldots \ldots \ldots \ldots \ldots \ldots \ldots \ldots \ldots \ldots \ldots \ldots \ldots \ldots \ldots \ldots \ldots \ldots \ldots$

EXECUTIVE SUMMARY $\ldots \ldots \ldots \ldots \ldots \ldots \ldots \ldots \ldots \ldots \ldots \ldots \ldots \ldots \ldots \ldots$

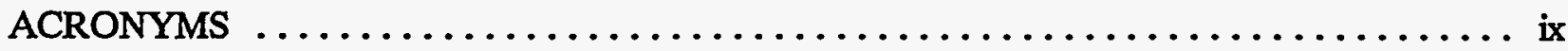

1. INITIAL INVESTIGATION $\ldots \ldots \ldots \ldots \ldots \ldots \ldots \ldots \ldots \ldots \ldots \ldots \ldots \ldots \ldots \ldots \ldots \ldots \ldots \ldots \ldots$

2. DESIGNATION UNDER RCRA $\ldots \ldots \ldots \ldots \ldots \ldots \ldots \ldots \ldots \ldots \ldots \ldots \ldots \ldots \ldots \ldots \ldots \ldots \ldots \ldots$

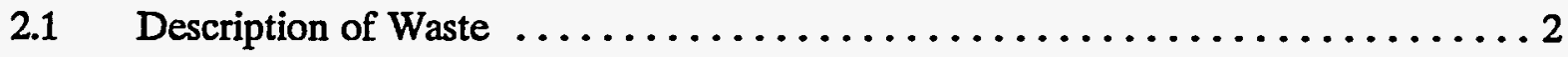

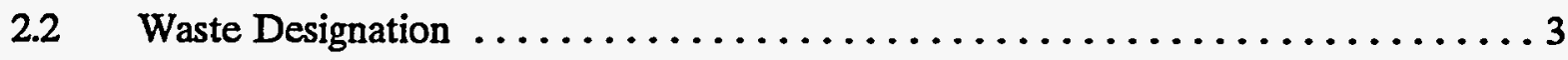

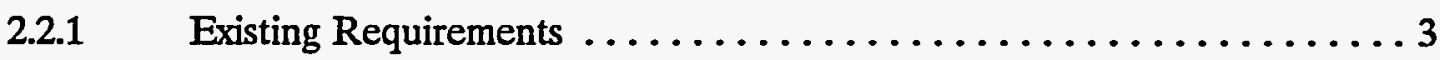

2.2.2 Do the Sealed Sources Constitute Solid Waste? .............. 3

2.2.3 Is the Waste Specifically Excluded? $\ldots \ldots \ldots \ldots \ldots \ldots \ldots \ldots \ldots$

2.2.4 Is the Waste Listed in Subpart $\mathrm{D}$ ? $\ldots \ldots \ldots \ldots \ldots \ldots \ldots \ldots \ldots \ldots \ldots \ldots \ldots \ldots \ldots$

2.2.5 Does the Waste Exhibit Hazardous Characteristics? ........... 9

2.3 Waste Designation Based on Future Requirements .............. 10

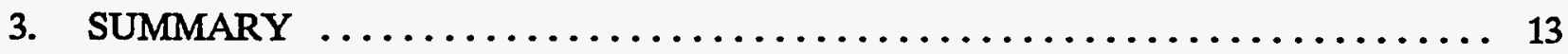

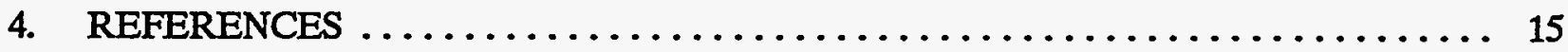

Appendix A-Letter from EPA to National Low-Level Waste Management Program ....... A-1

Appendix B-Descriptions of Representative Americium/Beryllium Sealed Sources ....... B-1

FIGURES

1. Logic diagram to designate a hazardous waste $\ldots \ldots \ldots \ldots \ldots \ldots \ldots \ldots \ldots$

2. Logic diagram to determine if a waste is a commercial chemical product $\ldots \ldots \ldots \ldots \ldots 5$

\section{TABLES}

1. Data from TCLP test (see Reference 5) $\ldots \ldots \ldots \ldots \ldots \ldots \ldots \ldots \ldots \ldots \ldots \ldots$

2. Summary of criteria and waste designation $\ldots \ldots \ldots \ldots \ldots \ldots \ldots \ldots \ldots \ldots \ldots$ 

$\ldots \ldots$ 


\section{ACRONYMS}

DOE U.S. Department of Energy

EPA U.S. Environmental Protection Agency

GTCC greater-than-Class C

$\mathrm{LC}_{50} \quad$ inhaled concentration of substance lethal to $50 \%$ of those exposed

$\mathrm{LD}_{50} \quad$ oral or intravenous dose of substance lethal to $50 \%$ of those exposed

NRC U.S. Nuclear Regulatory Commission

RCRA Resource Conservation and Recovery Act

TC Toxicity Characteristic

$\mathrm{TC}_{\mathrm{Lo}}$ toxic concentration low

TCLP Toxicity Characteristic Leaching Procedure

TIG tungsten inert gas 


\section{RCRA Designation of Discarded Americium/Beryllium Sealed Sources}

\section{INITIAL INVESTIGATION}

Telephone inquiries were conducted to determine whether major manufacturers and others had concluded that discarded americium/beryllium sealed sources (AmBe sources) constitute a hazardous waste under the Resource Conservation and Recovery Act (RCRA). Thirteen individuals were contacted. Only one individual stated that his company had examined the question of whether discarded AmBe sources were mixed waste (i.e., regulated under the Atomic Energy Act and RCRA). Another individual stated that his former company had determined that the discarded sources would not be mixed waste, but he did not volunteer a reason for this conclusion. He also stated that they had not committed this determination to writing.

Another individual stated that his corporation had not made an official determination, but "one would have to conclude that the sources are chemically hazardous." The conclusion was based on the highly toxic nature of beryllium, not on an evaluation against the RCRA criteria.

To evaluate the issue from a different position, the State of Washington was contacted to determine if AmBe sources that are not Greater-Than-Class C waste (GTCC) are acceptable at the Hanford disposal facility. The Washington Department of Health responded that similar sources were still being received at the Hanford commercial disposal facility. In fact, the Department of Health had given specific approval for the disposal of a radium/beryllium source the week before his response. Approval from the State was required due to the radioactive content of the source, not the hazardous component. The Department of Health was unaware of any restrictions that may be imposed due to the hazardous component of the waste.

The U.S. Nuclear Regulatory Commission (NRC) was also contacted. They had confronted the issue when a well-logging source was lost downhole, but did not reach a final conclusion.

The U.S. Environmental Protection Agency (EPA) Hotline was also contacted. The Hotline personnel did not know of any EPA directive that specifically deals with the issue of AmBe sources. However, Hotline personnel determined that the waste was not a listed RCRA waste. The Hotline personnel opined that it did not constitute a discarded commercial chemical product because it was "being used" in a commercial product. It should be noted that the Hotline's verbal determinations should not be solely relied upon.

Other EPA personnel were also contacted, and they were unaware of a written determination concerning AmBe sources. These individuals volunteered opinions that disposal of the sources is not RCRA-regulated, again because the beryllium was "being used" in a commercial product. After analyzing the first draft of this report, the EPA responded by letter, agreeing with the main conclusions. The letter is contained in Appendix A. 


\section{DESIGNATION UNDER RCRA}

This section provides justification for concluding that discarded sealed sources containing americium and beryllium are not regulated as hazardous waste under RCRA. This determination is valid for various source forms: leaking, intact, powdered, or nonpowdered.

\subsection{Description of Waste}

The construction details and characteristics of $\mathrm{AmBe}$ sealed sources selected for this study were obtained using the NRC Sealed Source and Device Catalogue. ${ }^{1}$ The NRC (and the Atomic Energy Commission before 1975) requires each sealed source and device utilizing sealed sources to be evaluated before distribution by the manufacturer. This evaluation is conducted by the regulatory authority, either the NRC or an Agreement State, ${ }^{a}$ with jurisdiction under the Atomic Energy Act. Consequently, a large compendium (the Catalogue) is available that describes the radiation hazards and general construction of all sealed sources licensed for use in the United States.

Although AmBe sources are or have been manufactured primarily by six principal source manufacturers (Amersham Corporation, DuPont, Merck Pharmaceuticals, General Radioisotope Products, Monsanto Company, and Gammatron), Amersham Corporation manufactures the vast majority of sources. The greatest use of $\mathrm{AmBe}$ sealed sources is in moisture/density gauges, where the source strength is a nominal $50 \mathrm{mCi}$. Other uses include well-logging and startup sources for nuclear reactors, with a nominal source strength of $20 \mathrm{Ci}$.

AmBe neutron sources are typically made from a mixture of ${ }^{241} \mathrm{Am}$ oxide (source powder) and beryllium oxide (target powder). These oxides are typically fine powders that are mixed and compressed into a pellet or the inner capsule of a "sealed source." The mixing and compression are essential to produce sources with constant and high neutron yield. Evidence suggests that early AmBe sources were not pelletized or held in rigid geometry, as neutron outputs from these early sources were reported to depend on geometry and were not constant. ${ }^{2}$ However, a brief review of current sealed source descriptions did not reveal any such sources. The source description for Amersham Model AMN-CYn (Series) states that the mixture of Am and Be powders is pressed into a pellet with a pressure of 10 tons/in ${ }^{2}$. This pressure is typical of Amersham sources. Data on other manufacturing processes were not available. Although the source descriptions did not contain the size of the pellets, pellets are usually larger in the highstrength sources. All sealed sources were doubly encapsulated in an alloy of stainless steel (e.g., 316, 316L, Monel, 304, 17-4PH). Typically, heliarc or tungsten inert gas (TIG) welding is used. AmBe sealed sources are usually right cylinders or annuli.

Some exceptional fabrication techniques were noted in the source descriptions. One source, Monsanto Model 24183, was reported to be "solution annealed" after the outer capsule was welded. This manufacturing process is no longer in use. Another source, Amersham Model

a. While the NRC has jurisdiction over nuclear materials licensing in some States, 28 States have opted to regulate such materials through their own regulatory agency. These States, known as Agreement States, have entered into agreements with the NRC to regulate certain by-product materials within their State. 
AMCL, did not mix beryllium powders with americium, but used an americium disk source that is "bound in a high fired ceramic substrate which is melted $\left(900^{\circ} \mathrm{C}\right)$ and bonded to a stainless steel insert." While the radioactive insert is doubly encapsulated, the window side consists of a 1-mm beryllium disk that is firmly fixed to the source using silver solder (melting point $960^{\circ} \mathrm{C}$ ). This source was not designed as a neutron source, but as a low-energy, gamma-emitting source having a window (beryllium) that offered minimum attenuation of the low-energy gammas. Another unusual source is Amersham Model AMN-6003, which was reported to have used ". . sintered americium oxide/beryllium oxide ceramic pellet," but a firing temperature was not provided in the source description. This source is no longer in active production, and Amersham Corporation no longer uses any sintering or ceramic processes in its source manufacture. ${ }^{b}$ AmBe sealed sources used in moisture density gauges may also incorporate a separate ${ }^{137} \mathrm{Cs}$ sealed source, or the ${ }^{137} \mathrm{Cs}$ may be contained in the same welded inner and outer containers as the AmBe, separated only by glass fiber or other packing and cushioning material.

A table and several figures illustrating some of the attributes of typical AmBe sources are provided in Appendix B.

\subsection{Waste Designation}

\subsubsection{Existing Requirements}

The existing requirements for designating hazardous waste are summarized in logic diagram format in Figures 1 and 2.

\subsubsection{Do the Sealed Sources Constitute Solid Waste?}

In the case of AmBe sealed sources for which the U.S. Department of Energy (DOE) has disposal responsibility under the Low-Level Radioactive Waste Policy Amendments Act of 1985, DOE must first determine if the sealed sources constitute solid waste as defined in 40 CFR 261.2.

By the time the DOE receives the sealed sources, they will probably have been "accumulated, stored, or treated (but not recycled) before or in lieu of being abandoned by being disposed of, burned, or incinerated" [40 CFR 261.2(b)(3)], and thus qualify as a solid waste. It should be noted, however, that the radioactive portions of the sources, i.e., the radioactive atoms of ${ }^{241} \mathrm{Am}$, are not a solid waste under the exemption provided in 40 CFR 261.4(a)(4) for by-

product material. If separable from the remainder of the source components, the ${ }^{241} \mathrm{Am}$ radioactive atoms would not constitute a solid waste. From a practical standpoint, however, the radioactive portion of the sources is mixed with materials that meet the definition of solid waste, and any separation technique would probably leave some ${ }^{241} \mathrm{Am}$ in contact with the beryllium. Therefore, for the purpose of this waste designation, the entire sealed source is considered a solid waste. If the sources are accumulated speculatively or reclaimed, they must also be considered solid wastes in accordance with 40 CFR 261.2(c).

b. Personal communication with Hugh Evans, Manager of Marketing, Amersham Corporation, September 9, 1991. 


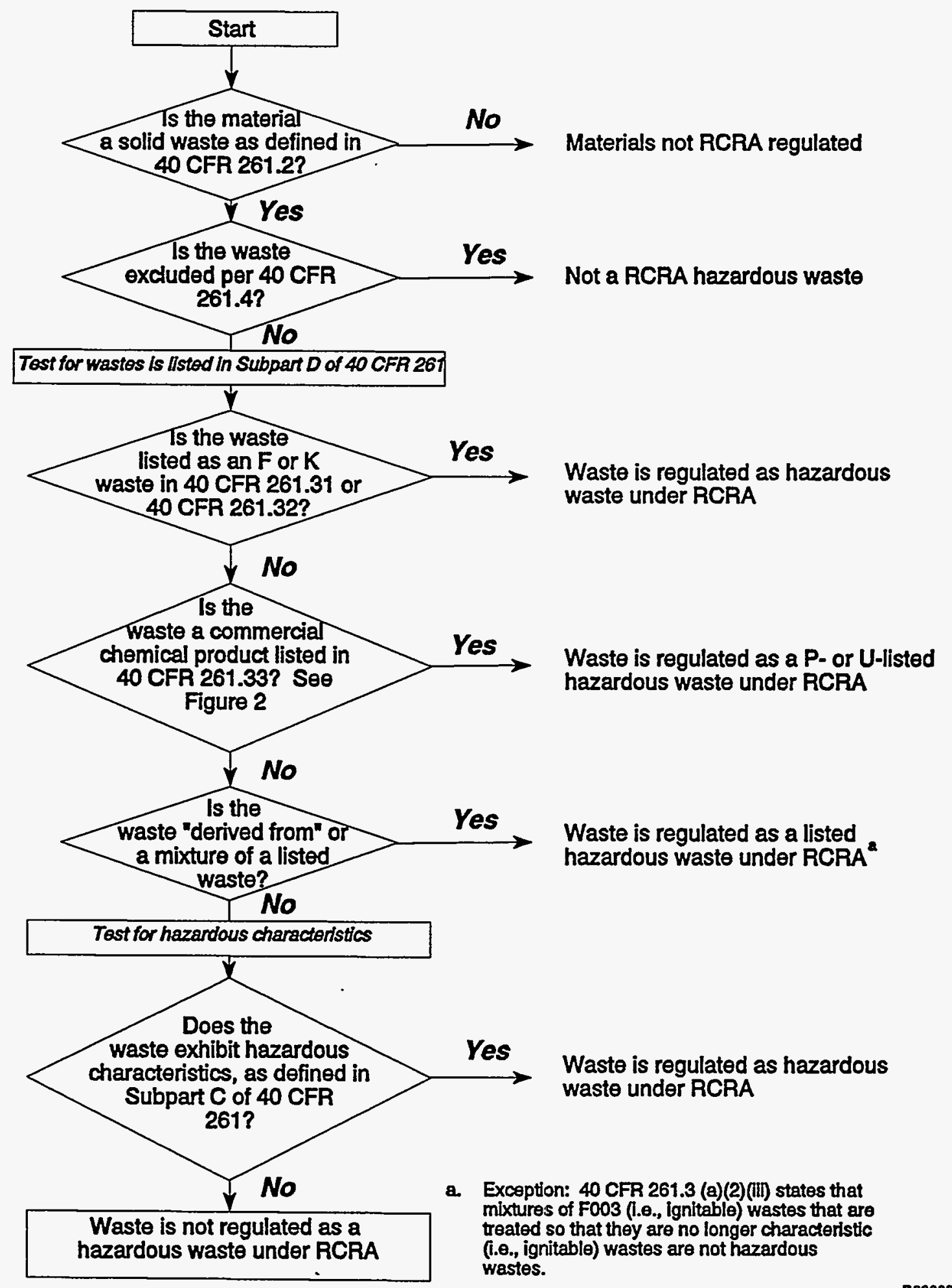

Figure 1. Logic diagram to designate a hazardous waste. 


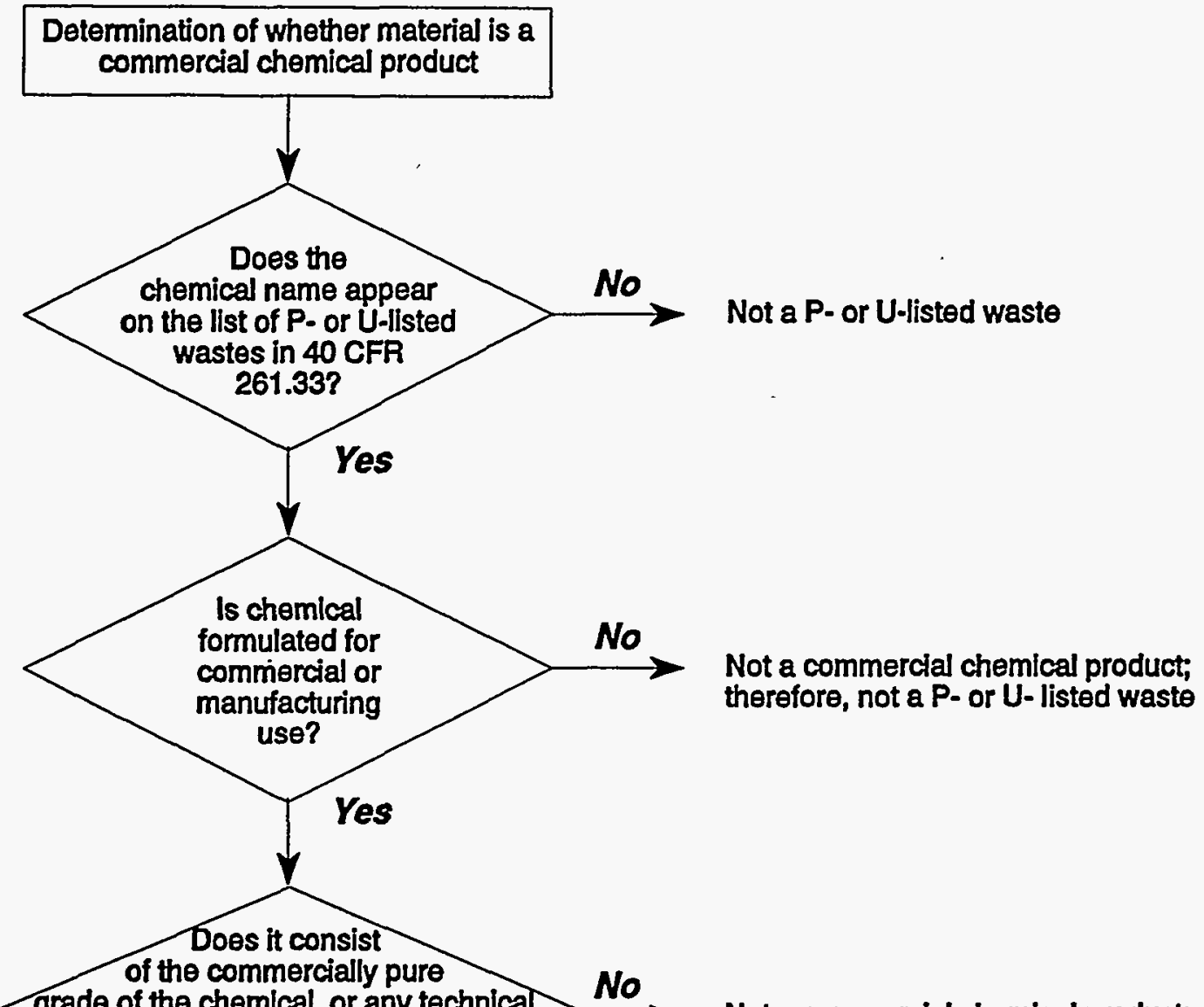

Not a commercial chemical product; therefore, not a P- or U-listed waste

\section{grade of the chemlcal, or any technica
grade of the chemical in which the}

thereforo, not a P-or U-listed wasto

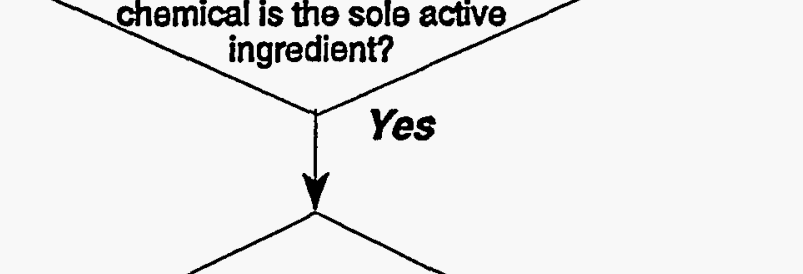

Has it boen

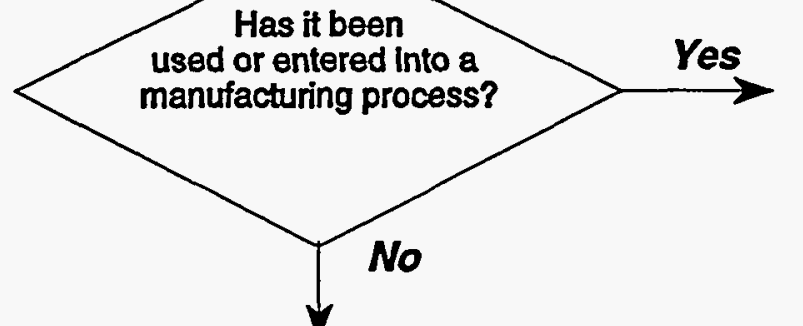

Waste is a process waste; therefore, not a P- or U- listed waste."

Waste is a commercial chemical product and a P- or U-listed waste a. Exception: If the process results in a waste in which the chemical is the sole active ingredient, the waste is a P-or U-listed wasto.

Figure 2. Logic diagram to determine if a waste is a commercial chemical product. 
If the sealed sources are solid waste, what is the status of the gauge or device that holds the sealed sources? The gauge or device holding the sealed sources is also considered a solid waste unless it is performing a useful function such as shielding. If the sources are removed from the device to reduce the volume of waste requiring disposal, both the device and the sealed sources would constitute solid waste and require evaluation as hazardous waste.

Next, a solid waste generator has the responsibility under 40 CFR 262.11 to determine if the solid waste is also a hazardous waste under RCRA. The following three tests are used to determine if solid waste is also a hazardous waste:

1. Is the waste specifically excluded from regulation under 40 CFR 261.4 ?

2. Is the waste listed as a hazardous waste in Subpart D of 40 CFR Part 261?

3. Does the waste exhibit one or more of the characteristics identified in Subpart C of 40 CFR Part 261, either by testing or through process knowledge?

Each of these tests is discussed below in relationship to the waste designation of AmBe sealed sources. This waste designation pertains only to the AmBe sealed sources and relies entirely on "process knowledge" as allowed by 40 CFR 262.11(c)(2).

\subsubsection{Is the Waste Specifically Excluded?}

EPA excludes certain solid wastes from regulation as hazardous wastes under $40 \mathrm{CFR}$ 261.4(b). These include household wastes, certain agricultural and mining wastes, specific air contaminants from the burning of fossil fuels, certain energy exploration and production drilling activities, specific trivalent chromium wastes, cement kiln dust wastes, certain wood products, certain petroleum-contaminated media, used refrigerants, in-process wastes, samples, treatability study samples, and samples undergoing treatability studies at testing facilities. There is no specific exclusion that pertains to $\mathrm{AmBe}$ sources.

\subsubsection{Is the Waste Listed in Subpart D?}

To be a listed hazardous waste in Subpart D of 40 CFR Part 261, the waste must either be generated from nonspecific sources (F-listed wastes), specific sources (K-listed wastes), or be discarded commercial chemical products, off-specification species, container residues, or spill residues thereof ( $\mathrm{P}$ - or U-listed wastes). However, none of the $28 \mathrm{~F}$-listed wastes describes an AmBe source. Similarly, none of the $101 \mathrm{~K}$-listed wastes pertain to discarded AmBe sources, nor do any of the more than 400 U-listed wastes.

The P-listed wastes, however, identify "beryllium powder" as a P015 waste. The applicability of this P-listed waste code depends on the definition of the phrase "commercial chemical product or manufacturing chemical intermediate."

c. Letter from Marcia Williams, Office of Solid Waste Management, U.S. Environmental Protection Agency, No Subject, to Terry Husseman, Washington Department of Ecology, June 26, 1987. 
According to the comment contained in 40 CFR 261.33(d),

The phrase "commercial chemical product or manufacturing chemical intermediate having the generic name listed in. .." refers to a chemical substance which is manufactured or formulated for commercial or manufacturing use which consists of the commercially pure grade of the chemical, any technical grades of the chemical that are produced or marketed, and all formulations in which the chemical is the sole active ingredient. It does not refer to a material, such as a manufacturing process waste, that contains any of the substances listed in paragraph (e) or (f). Where a manufacturing process waste is deemed to be a hazardous waste because it contains a substance listed in paragraph (e) or (f), such waste will be listed in either $\S 261.31$ or $\S 261.32$ or will be identified as a hazardous waste by the characteristics set forth in Subpart C of this part.

EPA recognized that the issue of listed wastes was likely to be confusing and provided guidance on when a chemical listed in 40 CFR 261.33 becomes a listed waste (45 FR 78541, November 25, 1980). In this preamble to the designation of P- and U-listed wastes, EPA provides the following guidance:

Are manufactured articles (such as battery and mercury vapor lights) that contain any of the chemicals listed in $\$ 261.33$ hazardous wastes by definition if they are discarded or intended to be discarded?

EPA intends that the materials listed in $\S 261.33$ include only those commercial [sic] chemical products and manufacturing chemical intermediates that are known by the generic name of the chemicals listed in paragraphs (e) and ( $f$ ) of that section. Manufactured articles that contain any of the chemicals listed in paragraphs (e) and (f) are rarely, if even [sic], known by the generic name of the chemical(s) they contain and, therefore, are not covered by the $\S 261.33$ listings. Should the Agency find it necessary to list any manufactured articles as hazardous wastes, it will initiate rulemaking to add these articles to $\$ 261.33$.

Because AmBe sources are manufactured articles containing one of the chemicals listed in 40 CFR 261.33(e) and the sources are not specifically listed elsewhere, AmBe sources would not qualify as a P-listed waste. EPA established the P-and U-listed wastes to halt indiscriminate dumping of unused portions of chemicals during the manufacturing process. These sealed sources, however, are the result of a manufacturing process, and the sources are intended for commercial use. In all but one source model, the beryllium was physically mixed with americium. The beryllium from these processes has become a manufactured article, and although it is intended for commercial or manufacturing use, it can no longer be considered a commercially pure grade of the chemical.

In the one source where the beryllium is not mixed with americium, the beryllium is shaped into a disk and serves as a window to allow passage of low energy gamma rays. Even though the beryllium disk is a pure form of beryllium, the manufacturing process converted the beryllium into a manufactured article. 
In all sealed sources evaluated, the beryllium is not a sole active ingredient in the sealed source, and it no longer retains its identity as a commercial chemical product. However, discarded beryllium residues generated during the manufacturing process for sealed sources may be considered a P015 waste.

EPA also provided guidance on the process whereby beryllium is recovered from a used source (45 FR 78540, November 25, 1980):

Are commercial products and manufacturing chemical intermediates listed in $\S 261.33$ subject to regulation if they are used, reused, recycled or reclaimed in lieu of being discarded?

No. A commercial chemical product or manufacturing chemical intermediate listed in $\S 261.33$ is a hazardous waste only if discarded or intended to be discarded. If it continues to be used or sold, it is not being discarded and therefore is not a hazardous waste. If it is an off-specification material and is reprocessed, recycled or reclaimed it is not being discarded and therefore is not a hazardous waste. Thus the provisions of $\S 261.6(\mathrm{~b})$ are not intended to apply to reuses of $\S 261.33$ materials, since in such cases the materials are never discarded.

Therefore, beryllium that is recovered and reused from recycled sealed sources does not qualify as a P-listed waste. However, any discarded beryllium powder residues/wastes from the recycling process would qualify as a P-listed waste.

To place the question of waste designation in another context, consider wastes from the manufacture of AmBe sources. It is probable that some beryllium may be left over in the production of any of the sources. Any pure beryllium that is discarded by the sealed source manufacturer or reclaimer would be a P015-listed waste. However, because the sources themselves are not a waste resulting from the manufacturing process, they are not a listed waste.

EPA provides additional guidance on the subject of mixtures in the same preamble ( $45 \mathrm{FR}$ 78540, November 25, 1980):

Are solid wastes that contain one or more of the chemicals listed in $\$ 261.33$ hazardous wastes by virtue of containing these materials?

Solid wastes which simply contain one of the chemicals listed in $\S 261.33$ are not thereby hazardous. Where EPA intends to list such wastes, it will do so by listing them in $\$ \S 261.31$ and 261.32 . . . The purpose of $\S 261.33$ is to regulate only the listed chemical products and intermediates and their trade name equivalent (and certain offspecification variants, emptied containers and spill residues and debris thereof) as hazardous wastes when they are discarded or intended to be discarded.

However, when a solid waste is mixed with one of these discarded materials, the resulting mixture is a hazardous waste until delisted. ... As set out in $\S 261.3(\mathrm{~b})(2)$, the solid waste becomes a hazardous waste when the mixing of the $\S 261.33$ chemical takes place either as an act of discarding that chemical or the time the chemical is 
intended for later discard (i.e., at the time the $\$ 261.33$ substance becomes a hazardous waste).

The beryllium in the AmBe sources was combined with the source capsule and the ${ }^{241} \mathrm{Am}$ during manufacture of the sealed source. The beryllium in the sealed source was not a waste at the time of manufacture of the source. Only after its manufacture, use, and/or discard did the sealed source become a waste. Because the mixing of the listed chemical with the ${ }^{241} \mathrm{Am}$ and source capsule occurred before the source became a waste, the AmBe sources do not qualify as a P-listed waste by virtue of the mixture rule.

Many of the discarded sealed sources that will be transferred to DOE have probably failed a leak test. That is, they have been identified as having at least $0.005 \mu \mathrm{Ci}$ of removable ${ }^{241} \mathrm{Am}$. While it would be difficult to prove that a leaking source did not contain beryllium powder, the P015 designation of the waste is determined by whether the beryllium is a commercial chemical product or manufacturing chemical intermediate, not whether the physical form of the beryllium is respirable. Since a leaking failed source remains a manufactured article and, in addition, the beryllium is not the sole active ingredient, a leaking sealed source is not a P-listed waste.

In summary, AmBe sealed sources are not P-listed waste because

1. They are not discarded commercial chemical products; the beryllium has been used for its intended purpose and combined with americium to produce the sealed source.

2. They are not off-specification species, container residues, or spill residues thereof.

\subsubsection{Does the Waste Exhibit Hazardous Characteristics?}

Characteristic wastes are those that exhibit the characteristics of ignitability, corrosivity, reactivity, or toxicity. A solid waste is ignitable if it is ". . capable, under standard temperature and pressure, of causing fire through friction, absorption of moisture or spontaneous chemical changes and, when ignited, burns so vigorously and persistently that it creates a hazard" [ 40 CFR 261.21(a)(2)]. Stainless steel is known to be an inert material. Americium has a melting point of $944^{\circ} \mathrm{C}$ and a boiling point of $2,607^{\circ} \mathrm{C}$; the melting point and boiling point of beryllium is $1,278^{\circ} \mathrm{C}$ and $2,970^{\circ} \mathrm{C}$ (at $5-\mathrm{mm}$ pressure), respectively. Consequently, sealed sources composed primarily of americium, beryllium, and stainless steel are not ignitable.

The characteristic of corrosivity is defined only for liquids in 40 CFR 261.22. The AmBe sources are not liquid and, therefore, do not by definition exhibit the characteristic of corrosivity.

The characteristic of reactivity is defined in 40 CFR 261.23, and can be summarized as readily or violently reacting or changing either by detonation or reaction with water, generating toxic gases when mixed with water, having the capability to generate hydrogen sulfide or hydrogen cyanide gases under specified conditions, or being an explosive. In considering whether sealed sources of AmBe exhibit the characteristic of reactivity, note that americium and beryllium do not dissolve readily in water. In addition, because of their chemical composition, they are incapable of generating hydrogen sulfide or hydrogen cyanide gas. They routinely undergo exposure to high temperatures and pressures during manufacture and subsequent transportation testing without 
showing any signs of reactivity. Many of these sealed sources are tested to meet U.S. Department of Transportation (DOT) requirements for what the DOT terms "Special Form" materials. Special Form sealed sources have been heated to $1,475^{\circ} \mathrm{F}$ for 10 minutes, immersed in water for 24 hours, and dropped onto an essentially unyielding surface without loss of source integrity. It can be confidently concluded, therefore, that americium, beryllium, and AmBe sealed sources do not exhibit the characteristic of reactivity.

Toxicity characteristic (TC) wastes are those that, when subjected to the specified Toxicity Characteristic Leaching Procedure (TCLP), ${ }^{3}$ produce a leachate that exceeds specified concentration levels for any of 40 chemicals listed in 40 CFR 261.24. While neither beryllium nor americium is listed as a TC contaminant, elements known to be present in stainless steel such as chromium and those present in solder such as silver are listed as TC contaminants. The allowable TC concentration in the TCLP leachate for chromium or silver is $5,000 \mu \mathrm{g} / \mathrm{L}$. Because the TCLP test requires grinding of the waste (in this case a sealed source) and consequential loss of sealed source integrity, basic radiation protection precepts demand that alternative means be used to determine if the waste exhibits TC. EPA has stated that it is considering a TCLP test for monolithic waste (55 FR 11798, March 29, 1990), but such a test has not yet been approved.

To definitively answer the question of whether AmBe sealed sources qualify as TC hazardous waste, additional research into trace contaminants in stainless steel encapsulation and silver solder was performed on 50-mg samples of 304 stainless steel and silver solder. Series 304 stainless steel was chosen because this material is frequently used in nuclear applications, and has a relatively high chromium content of $18-20 \% .^{4}$ Other sealed source capsule materials, such as 316 stainless steel, 17-4 $\mathrm{PH}$, or Monel, have the same or lower chromium content and would be expected to leach chromium about the same or even less. Silver solder ( $85 \%$ silver and $15 \%$ manganese as specified by Amersham for model AMCL source) was also used for the TCLP extraction with subsequent analysis using an inductively coupled Plasma Atomic Emission Spectrometer. Data from these tests are shown in Table 1.5 A very low concentration of chromium was detected in the stainless steel sample (2.5\% of the regulatory limit). Similarly, a low concentration of silver was reported in the silver solder extract ( $<1 \%$ of the regulatory limit). Data validation for these laboratory results confirmed that neither the silver value for the sample of silver solder nor the chromium value for the sample of stainless steel exceeded the TCLP regulatory limits specified in 40 CFR 261.24.

These TCLP results were from samples that consisted entirely of either 304 stainless steel or silver solder. The fabricated AmBe sealed source would have only a small percentage of its weight comprised of stainless steel or solder materials. Therefore, a TCLP test of the actual source capsule would yield even lower concentrations of silver and solder in the leachate.

Consequently, based on process knowledge and testing data, it can be concluded that $\mathrm{AmBe}$ sealed sources do not constitute a RCRA toxicity characteristic waste.

\subsection{Waste Designation Based on Future Requirements}

Because of the long lead times associated with fundamental decisions involving the high-level radioactive waste repository, and because of the indirect way in which radioactive waste became regulated under RCRA, it is prudent to consider the general criteria for listing of hazardous 
Table 1. Data from TCLP test (see Reference 5).

\begin{tabular}{lcl}
\multicolumn{1}{c}{ Sample } & $\begin{array}{c}\text { Chromium } \\
(\mu \mathrm{g} / \mathrm{L})\end{array}$ & \multicolumn{1}{c}{$\begin{array}{c}\text { Silver } \\
(\mu \mathrm{g} / \mathrm{L})\end{array}$} \\
\hline Stainless Steel 304 & 125 & NR \\
Silver Solder & $\mathrm{NR}$ & $3.5(\mathrm{UJ})$
\end{tabular}

NR - Not Requested

UJ - The material was analyzed for, but was not detected. The associated value is an estimate and may be inaccurate or imprecise.

waste. Such consideration would help to determine if it is likely that EPA may list neutron sources with beryllium targets as future $\mathrm{F}$ - or $\mathrm{K}$-listed wastes.

The criteria for listing hazardous waste are contained in 40 CFR 261.11. Beryllium is listed because of its toxicity. EPA provides the following criteria for the "Acute Hazardous Waste" designation at 40 CFR 261.11(a)(2). A waste is an Acute Hazardous Waste if it is

found to be fatal to humans in low doses or, in the absence of data on human toxicity, it has been shown in studies to have an oral $L D_{50}{ }^{d}$ toxicity (rat) of less than 50 milligrams per kilogram, an inhalation $\mathrm{LC}_{50}{ }^{\mathrm{e}}$ toxicity (rat) of less than 2 milligrams per liter, or a dermal $L D_{50}$ toxicity (rabbit) of less than 200 milligrams per kilogram or is otherwise capable of causing or significantly contributing to an increase in serious irreversible, or incapacitating reversible, illness.

Beryllium is a highly toxic metal having an $\mathrm{LD}_{50}$ for rats of $496 \mu \mathrm{g} / \mathrm{kg}$ by intravenous injection and a $\mathrm{TC}_{\mathrm{Lo}}{ }^{\mathrm{f}}$ in humans of $300 \mathrm{mg} / \mathrm{m}^{3}$ by inhalation. ${ }^{6}$ (Note: The EPA definitions of Acute Hazardous Waste derive from the DOT designation of a Class B poison.)

In this regard, there are three areas of potential vulnerability for neutron sources having beryllium targets:

d. $L D_{50}=$ The single oral or intravenous dose of a substance that causes death to $50 \%$ of an animal population.

e. $L C_{50}=$ The single exposure to an inhaled substance that causes death to $50 \%$ of an animal population.

f. $\mathrm{TC}_{\mathrm{LO}_{\mathrm{O}}}=$ Toxic concentration low. The lowest concentration of a substance in air to which humans or animals have been exposed that has produced any toxic effect (tumorigenic, reproductive). 
1. The possibility of causing an inhalation $\mathrm{LC}_{50}$ toxicity in a rat at less than $2 \mathrm{mg}$ per liter (48-hr exposure).

2. The possibility that the chemical nature of the sealed source is capable of causing or significantly contributing to an increase in serious irreversible or incapacitating reversible illness.

3. The possibility that the EPA Administrator concludes that the waste is capable of posing a substantial present or potential hazard to human health or the environment when improperly treated, stored, transported, disposed of, or otherwise managed in accordance with the criteria identified in 40 CFR 261.11(3).

The possibility of EPA acting to regulate this waste involves factors well beyond DOE's control. However, barring a major accident involving an AmBe source, it is likely that the EPA would consider that the radiological controls for sealed sources would provide an ample margin of safety to control the toxic nature of beryllium.

An example of the routine controls placed on sealed sources is the requirement that sealed sources be leak tested at 6-month intervals and whenever source integrity is questioned. A source showing contamination of more than $0.005 \mu \mathrm{Ci}$ is considered leaking. Assuming that the americium-to-beryllium ratio of Amersham Model AMN.V340 is representative of all AmBe sources, $650 \mathrm{mg}$ of beryllium is mixed with $350 \mathrm{mCi}$ of ${ }^{241} \mathrm{Am}$. This ratio is approximately $1.86 \mathrm{mg}$ of beryllium per $\mathrm{mCi}$ of ${ }^{241} \mathrm{Am}$. Thus, a leaking radioactive source will be accompanied by the release of about $9.29 \times 10^{-6} \mathrm{mg}(9 \mathrm{ng})$ of beryllium. This beryllium level for a leaking source is well within the capability of chemical analytical detection techniques, thus providing greater assurance of protection to human health and the environment than some other source of beryllium without the radioactive tracer and semiannual testing schedule. 


\section{SUMMARY}

AmBe sealed sources are determined not to be hazardous waste under RCRA. A summary of the criteria leading to this conclusion is provided in Table 2.

This determination is based on Federal regulations and criteria. Hazardous waste programs delegated to and administered by States, however, may develop more stringent criteria.

Table 2. Summary of criteria and waste designation.

\begin{tabular}{|c|c|c|c|}
\hline Designation & $40 \mathrm{CFR}$ & Applicable? & Reasons \\
\hline Solid waste & 261.2 & Yes & $\begin{array}{l}\text { DOE acceptance of sealed sources as waste } \\
\text { meets RCRA definition of solid waste }\end{array}$ \\
\hline $\begin{array}{l}\text { Excluded as hazardous } \\
\text { waste }\end{array}$ & 261.4(b) & No & $\begin{array}{l}\text { Sealed sources do not meet any of the } \\
\text { exclusion criteria }\end{array}$ \\
\hline F-listed waste & 261.31 & No & $\begin{array}{l}\text { AmBe sealed sources do not fit any of the } \\
\text { nonspecific source listings }\end{array}$ \\
\hline K-listed waste & 261.32 & No & $\begin{array}{l}\text { AmBe sealed sources do not fit any of the } \\
\text { specific source listings }\end{array}$ \\
\hline $\begin{array}{l}\text { Discarded commercial } \\
\text { chemical products }\end{array}$ & 261.33 & No & $\begin{array}{l}\text { Manufactured articles are not discarded } \\
\text { commercial chemical products }\end{array}$ \\
\hline Ignitable & 261.21 & No & $\begin{array}{l}\text { Chemical properties of } \mathrm{Am}, \mathrm{Be} \text { or } \mathrm{AmBe} \\
\text { sealed sources do not meet definition of } \\
\text { ignitable waste }\end{array}$ \\
\hline Corrosive & 261.22 & No & Corrosivity is not defined for a solid \\
\hline Reactive & 261.23 & No & $\begin{array}{l}\text { Chemical properties of } \mathrm{Am}, \mathrm{Be} \text { or } \mathrm{AmBe} \\
\text { sealed sources do not meet definition of } \\
\text { reactive waste }\end{array}$ \\
\hline Toxic & 261.24 & No & $\begin{array}{l}\text { Stainless steel, silver solder, Am, and Be } \\
\text { components do not leach TC contaminants in } \\
\text { sufficient concentration to be considered toxic. }\end{array}$ \\
\hline Conclusion & $\begin{array}{l}40 \text { CFR } \\
\text { Part } 261\end{array}$ & - & $\begin{array}{l}\text { Discarded AmBe sealed sources are not } \\
\text { RCRA regulated as hazardous waste. }\end{array}$ \\
\hline
\end{tabular}




\section{REFERENCES}

1. U.S. Nuclear Regulatory Commission, Sealed Source and Device Catalogue, Washington, D.C., September 1991.

2. U.S. Department of Commerce, Measurement of Neutron Flux and Spectra for Physical and Biological Applications, National Bureau of Standards Handbook 72, Washington, D.C., 1960.

3. Code of Federal Regulations, 40 CFR 261, Appendix II, Method 1311, "Toxicity Characteristic Leaching Procedure (TCLP)," Office of the Federal Register, Revised July 1992.

4. Joseph T. Ryerson \& Son, Inc., Data Book, Multiple Locations, 1967.

5. EG\&G Idaho, Inc., Toxicity Characteristic Leachability Procedure Findings for a SilverManganese Solder Sample and a 304 Stainless Steel Sample, DOE/LLW-177, May 1993.

6. U.S. Department of Health and Human Services, National Institute of Occupational Safety and Health (NIOSH), Registry of Toxic Effects of Chemical Substances, Volume 2, 1985. 
Appendix A

Letter from EPA to National Low-Level

Waste Management Program 
Roger L. Scoth, Manager

National Low-Level

Waste Management Program

EG\&G Idaho, Inc.

Idaho Falls, Idaho 83415

Dear Mr. Scott:

Thank you for forwarding your report entitled "Designation of Americium Beryllium Sources under RCRA" to the Office of Solid Waste. We greatly appreciate your effort in characterizing americium beryllium ( $\mathrm{AmBe}$ ) sealed source wastes. The resolution of the issue is important, because as you indicate, there are several thousand discarded sealed sources which mav enter the radioactive waste stream annually. My staff in the Permits and State Programs Division and the Characterization and Assessment Division have reviewed the report, and view it as a very thorough and well done repor.

As a general matter, we agree with your tentative determination that AmBe sealed sources are not hazardous under the Resource Conservation and Recovery Act (RCRA). As your report suggests, discarded AmBe sealed sources would not be P-listed commercial chemical product or chemical intermediate wastes, despite their beryllium content (P015), since the commercial chemical product listings in 40 CFR 261.33 do not extend to manufactured products which are discarded after their end use. In addition, we agree that there would not be any corrosive, ignitable, or reactive properties associated with these sealed sources, nor do we expect stainless steel casings to fail the Toxicity Characteristic (TC). Situations that may cause stainless or specialty steel components (NI, CR) to fail the TC are where a pipe or piece of machinery takes a physical beating (e.g., is etched) by material in contact with it

It is less clear whether the solder will pass the TC. Given the safety concerns with mixed wastes, a combination testing/mass balance approach may be appropriate to characterize solder from sealed sources. Either information on the composition of the solder, or TCLP testing (on a non-radioactive sample) would be a starting point. Then, based upon the percentage of the whole material that is solder, a "theoretical" TCLP concentration may be determined, using an assumption of no contribution of TCLP constituents from the non-solder portion of the waste.

It also appears to be unlikely that any trace amounts of $\mathrm{TC}$ metals in the americium 
and beryllium will cause the sealed sources to fail the TC unless there is a large amount of Am or $\mathrm{Be}$ in the capsule.

My staff offers the following specific comments on your report:

1. On page II-3, Figure II-1, the third decision triangle in the series asks "Is the Waste Listed as P or U Waste in 40 CFR 261.33?" The decision to the right of the triangle says "Yes or Maybe". We suggest you remove the word maybe because it is vague and not explained.

2. On page II-5, Section 2.1.3, the last sentence refers to identifying "beryllium EPA changed th powder" as P015 waste. We suggest you delete the word "powder" since P015 is designated as "beryilium" not "beryllium powder" in 40 CFR 261.33.

3. On page II- 6 , in the last paragraph, you may want to mention that discarded beryllium residues generated during the manufacturing process for sealed sources may be considered P015 wastes.

Pols designation to include "powider in June 1994; therefore, the report still says "berylium peinder:", - Sept:'74

4. On page II-8, we suggest you delete the word "powder" in the second full paragraph for the reason set forth in comment 2.

Again, I commend the thoroughness of your effort to characterize discarded Americium Beryllium sealed sources as potential mixed waste streams. While we agree generally with the conclusions you have reached under the Federal RCRA requirements, I should remind you that States authorized under RCRA for mixed waste may have more stringent hazardous waste regulations than the Federal requirements. Should you have any additional questions, please call Richard LaShier or Susan Jones at (202) 260-2210.

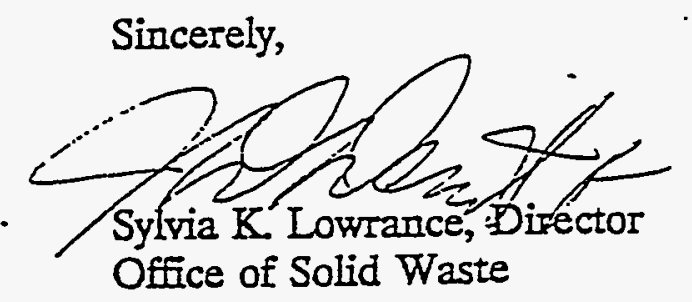




\section{Appendix B \\ Descriptions of Representative Americium/ Beryllium Sealed Sources}


B-2 


\section{Appendix B}

\section{Descriptions of Representative Americium/ Beryllium Sealed Sources}

The following is a list of typical americium/beryllium sealed sources. Models are described in Table B-1. Figures B-1, B-2, and B-3 depict models Amersham AMCL, AMN-PEn, and Monsanto 24013, respectively.

\begin{tabular}{ll}
\hline Manufacturer/Distributor & \multicolumn{1}{c}{ Model Numbers } \\
\hline Amersham Corporation & AMN-6002; AMN-6003; AMN-2254; AMCL; AMN-241; AMN- \\
& V997; AMN-24 and 25; AMN-19 and 22; AMN-CYn; AMN-PEn; \\
& VD; VD (HP) \\
Monsanto Company & 2722-BT; 24154-A, B, and C, 2726-Bx; H 245258 (NSR-M); 24113; \\
& 2720 A, B, or C; 24181; 24183; 24195; 24194; 24197; 24107 \\
DuPont NEN & RNG.1; NER-550; NER-560; NER-560-A \\
General Radioisotope & $6082 ; 7022 ; 6002$ \\
Inactive Sources & \\
Amersham Corporation & XN-1 \\
Atomic Energy of Canada & C-143 \\
Gamma Industries & NB-S-5 and 20
\end{tabular}

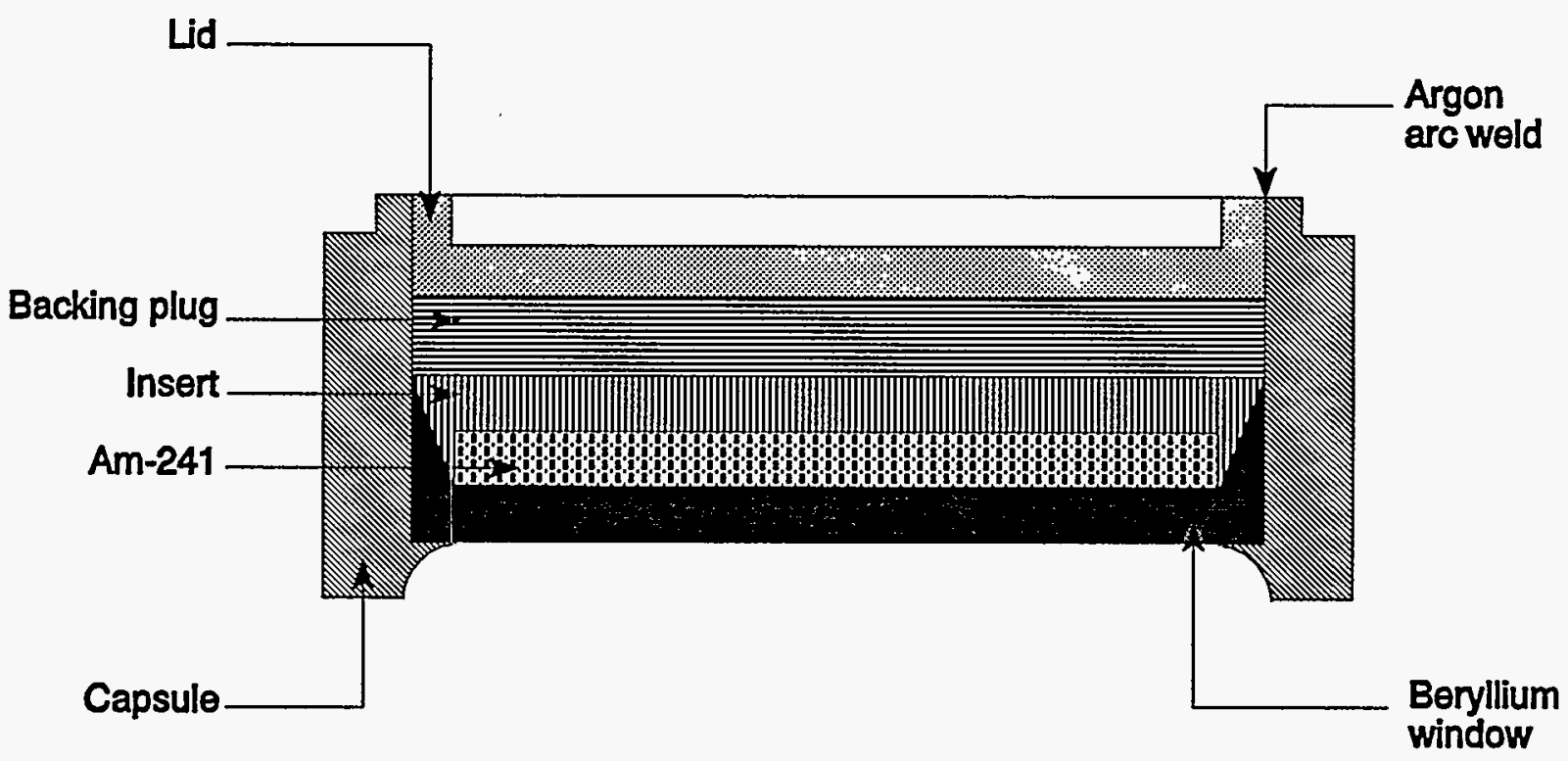

D23008D

Figure B-1. Cross section of Amersham AMCL. 


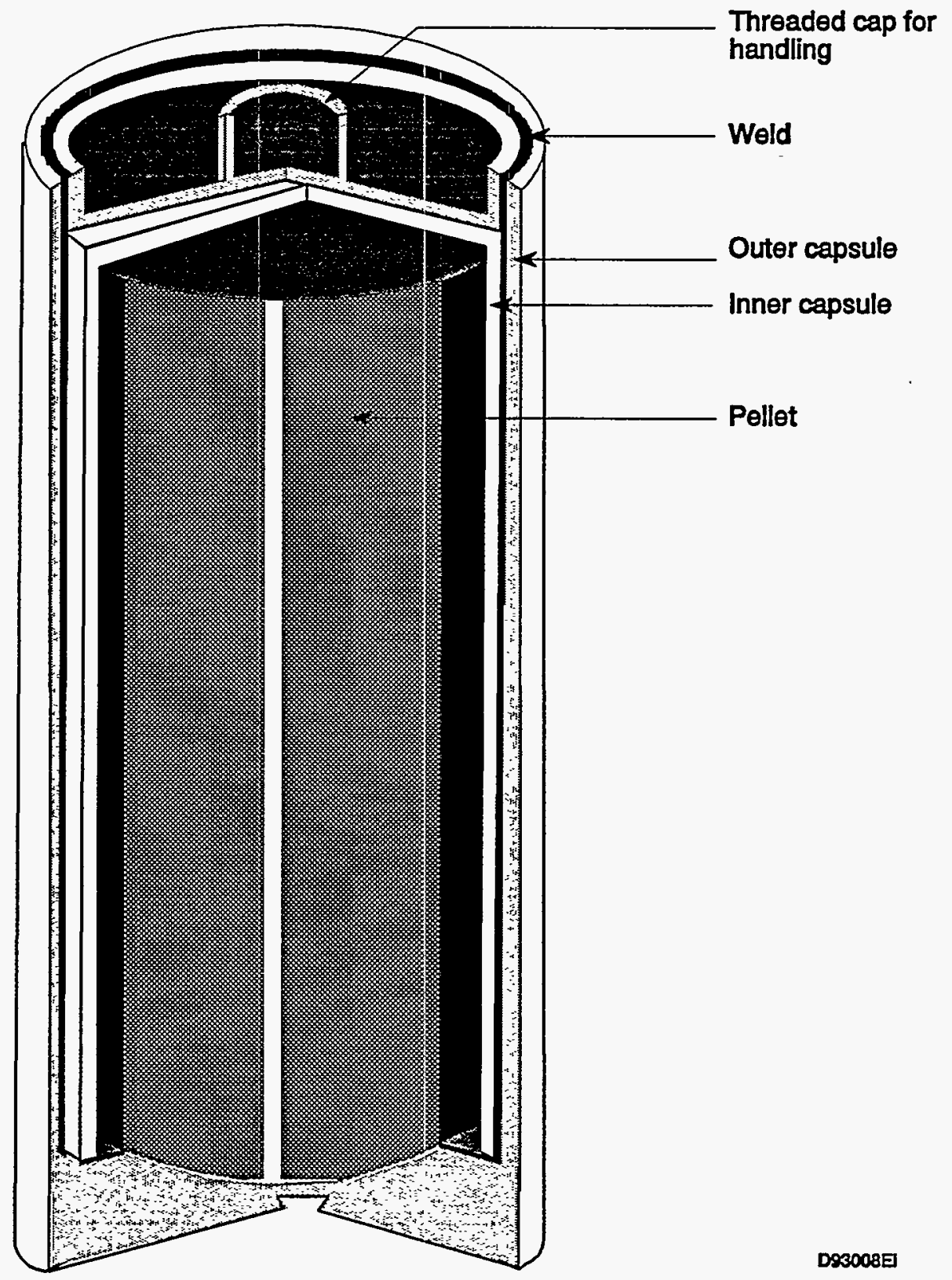

Figure B-2. Cutaway view of Amersham AMN-PEn. 


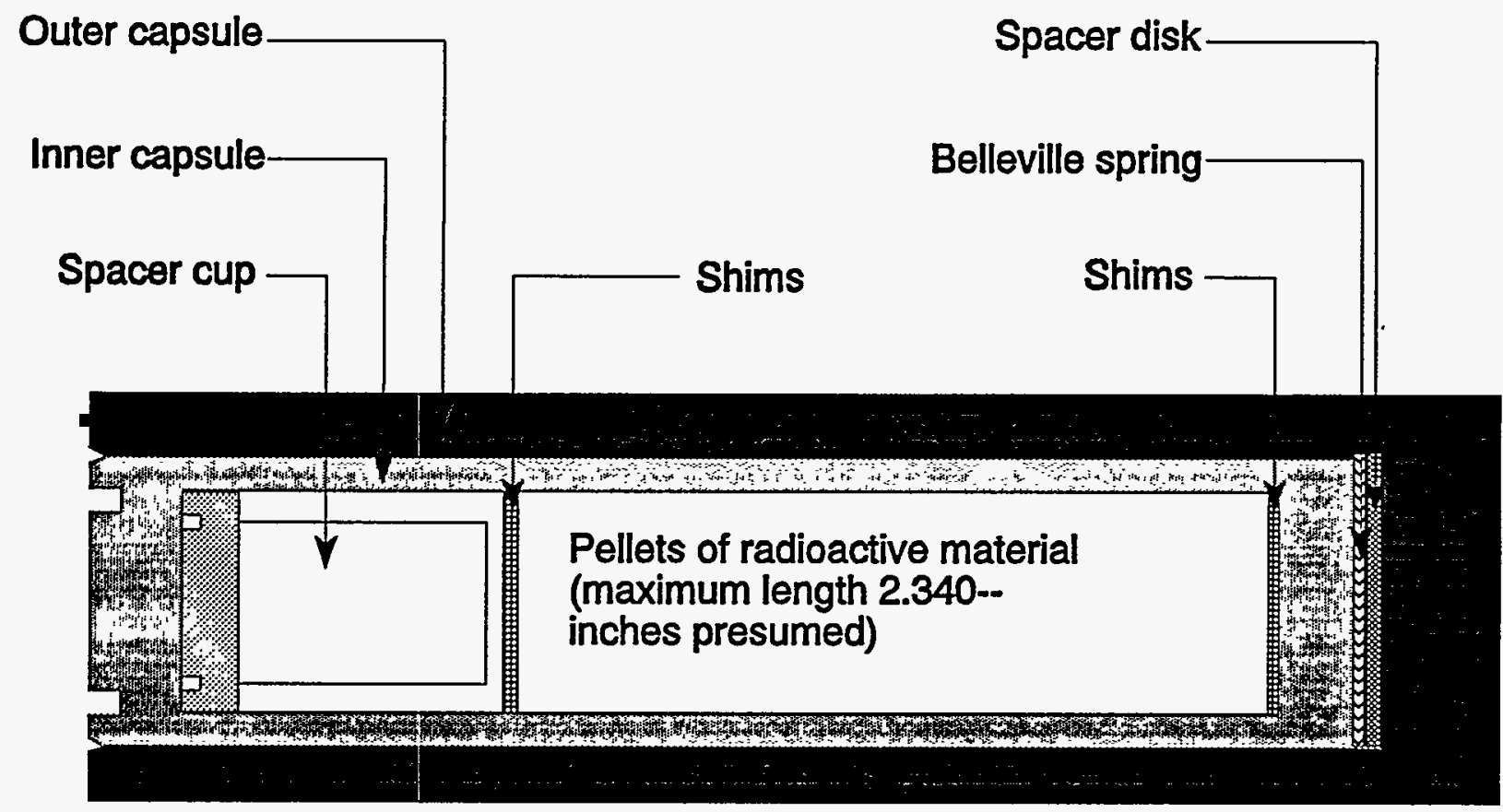

D93008C

Figure B-3. Cross section of Monsanto 24113. 
Table B-1. Descriptions of representative americium-beryllium sealed sources.

\begin{tabular}{|c|c|c|c|c|c|c|}
\hline $\begin{array}{l}\text { Manufacturer/ } \\
\text { distributor }\end{array}$ & $\begin{array}{c}\text { Model } \\
\text { (date evaluated) }\end{array}$ & Strength & Form & $\begin{array}{c}\text { Capsule } \\
\text { material/size }\end{array}$ & Welding & $\begin{array}{l}\text { Neutron } \\
\text { emission }\end{array}$ \\
\hline \multirow[t]{4}{*}{$\begin{array}{l}\text { Amersham Corporation } \\
2636 \text { S. Clearbrook Dr. } \\
\text { Arlington Heights, IL } \\
60005\end{array}$} & $\begin{array}{l}\text { AMN-6002 } \\
(6 / 10 / 71)\end{array}$ & $\begin{array}{l}50 \mathrm{mCi} \text { of }{ }^{241} \mathrm{Am} \\
10 \mathrm{mCi} \text { of }{ }^{137} \mathrm{Cs}\end{array}$ & $\begin{array}{l}{ }^{211} \mathrm{Am} \text { oxide/beryllium pellet and } \\
\text { cesium in a glass bead }\end{array}$ & $\begin{array}{l}316 \text { stainless steel } \\
\text { nominal; } \\
0.35 \text { in. diameter/ } \\
0.51 \text { in. length; } \\
\text { ANSI N5.10- } \\
1968 \text { C } 44345\end{array}$ & Argon Arc & $\begin{array}{l}1.1 \times 10^{5} \\
\mathrm{n} / \mathrm{sec}\end{array}$ \\
\hline & $\begin{array}{l}\text { AMN-6003 } \\
(8 / 1 / 71)\end{array}$ & $125 \mathrm{mCi}$ of ${ }^{241} \mathrm{Am}$ & $\begin{array}{l}\text { Sintered }{ }^{241} \mathrm{Am} \text { oxide/beryllium oxide } \\
\text { ceramic pellet and cesium in a glass } \\
\text { bead }\end{array}$ & $\begin{array}{l}316 \text { stainless steel } \\
\text { nominal; } \\
0.35 \text { in. diameter/ } \\
0.57 \text { in. length; } \\
\text { ANSI N5.10- } \\
1968 C 44345\end{array}$ & Argon Arc & $\begin{array}{l}1.1 \times 10^{5} \\
\mathrm{n} / \mathrm{sec}\end{array}$ \\
\hline & $\begin{array}{l}\text { AMN-2554 } \\
(2 / 25 / 74)\end{array}$ & $60 \mathrm{mCi}$ of ${ }^{241} \mathrm{Am}$ & $\begin{array}{l}\text { This source consists of }{ }^{241} \mathrm{Am} \\
\text { contained in an insoluble, leach- } \\
\text { resistant, nonporous ceramic pellet, } \\
\text { ceramic fiber packing. }\end{array}$ & $\begin{array}{l}316 \text { stainless steel; } \\
10 \mathrm{~mm} \text { long; } \\
0.5 \mathrm{~mm} \text { wall } \\
\text { thickness; ANSI } \\
\text { C44444 }\end{array}$ & Argon Arc & $?$ \\
\hline & $\begin{array}{l}\text { AMCL } \\
(10 / 15 / 84) \\
\text { (see Figure B-1) }\end{array}$ & $100 \mathrm{mCi}$ of ${ }^{241} \mathrm{Am}$ & $\begin{array}{l}\text { As an oxide, the radioactive material } \\
\text { is bound in a high-fired ceramic } \\
\text { substrate that is melted }\left(900^{\circ} \mathrm{C} \text { ) and }\right. \\
\text { bonded to a stainless steel insert. The } \\
\text { insert is placed into a heavy-walled } \\
\text { Monel capsule, which is sealed on the } \\
\text { back side by welding a backing plug } \\
\text { and Monel lid to the capsule wall. } \\
\text { The window side of the crucible } \\
\text { consists of a 1-mm thick beryllium } \\
\text { disk that butts against a shoulder in the } \\
\text { capsule wall and is firmly fixed in } \\
\text { position by silver solder (melting point } \\
960^{\circ} \mathrm{C} \text { ). }\end{array}$ & $\begin{array}{l}\text { Mionei diameter } \\
\text { varies from } 8 \text { to } \\
15 \mathrm{~mm} \text {; length } \\
5 \mathrm{~mm} \text {; ANSI N542 }\end{array}$ & Árgon Árc & $?$ \\
\hline
\end{tabular}


Table B-1. (continued).

\begin{tabular}{|c|c|c|c|c|c|c|}
\hline $\begin{array}{l}\text { Manufacturer/ } \\
\text { distributor }\end{array}$ & $\begin{array}{c}\text { Model } \\
\text { (date evaluated) }\end{array}$ & Strength & Form & $\begin{array}{c}\text { Capsule } \\
\text { material/size }\end{array}$ & Welding & $\begin{array}{l}\text { Neutron } \\
\text { emission }\end{array}$ \\
\hline \multirow{6}{*}{$\begin{array}{l}\text { Amersham Corporation } \\
2636 \text { S. Clearbrook Dr. } \\
\text { Arlington Heights, IL } \\
60005\end{array}$} & $\begin{array}{l}\text { AMN-V340 } \\
(4 / 11 / 75)\end{array}$ & $\begin{array}{l}350 \mathrm{mCi} \text { of } \\
{ }^{241} \mathrm{Am}\end{array}$ & $\begin{array}{l}\text { Pellet consisting of }{ }^{241} \mathrm{Am} \text { oxide that is } \\
\text { uniformly dispersed throughout a } \\
\text { matrix of } 650 \mathrm{mg} \text { of beryllium metal }\end{array}$ & $\begin{array}{l}\text { Inner capsule: } \\
316 \mathrm{~L} \text { stainless steel } \\
0.5 \mathrm{~mm} \text { thick; }\end{array}$ & $\begin{array}{l}\text { Tungsten } \\
\text { Inert Gas } \\
\text { (TIG) }\end{array}$ & $1.2 \times 10^{6}$ \\
\hline & & & & $\begin{array}{l}\text { Outer Capsule: } \\
316 \mathrm{~L} \text { stainless steel } \\
1 \mathrm{~mm} \text { thick; }\end{array}$ & & \\
\hline & & & & $\begin{array}{l}12.7 \mathrm{~mm} \text { diameter; } \\
12.7 \mathrm{~mm} \text { length }\end{array}$ & & \\
\hline & & & & ANSI: C44444 & & \\
\hline & $\begin{array}{l}\text { AMN-V997 } \\
(10 / 17 / 75)\end{array}$ & $\begin{array}{l}40 \mathrm{mCi} \text { of } \\
{ }^{241} \mathrm{Am}\end{array}$ & $\begin{array}{l}\text { A doubly encapsulated pellet, } \\
\text { consisting of }{ }^{241} \mathrm{Am} \text { oxide that is } \\
\text { uniformly dispersed through a matrix } \\
\text { of beryllium metal }\end{array}$ & $\begin{array}{l}\text { Type XI capsule: } \\
316 \text { stainless steel; } \\
1.6 \mathrm{~mm} \text { thick; } \\
7.8 \times 9.8 \mathrm{~mm} \\
\text { O.D. (Rt. cylinder) }\end{array}$ & TIG & \\
\hline & & & & ANSI C54444 & & \\
\hline \multirow[t]{4}{*}{, } & $\begin{array}{l}\text { AMN-24 } \\
\text { AMN-25 } \\
(12 / 20 / 77)\end{array}$ & $\begin{array}{l}5 \text { to } 10 \mathrm{Ci} \\
{ }^{241} \mathrm{Am}\end{array}$ & $\begin{array}{l}\text { A doubly encapsulated pellet of } \\
\text { Am- } 241 \text { oxide that is uniformly } \\
\text { dispersed through a matrix of } \\
\text { beryllium metal }\end{array}$ & $\begin{array}{l}\text { Inner and outer } \\
\text { capsules: } \\
\text { 316L stainless steel }\end{array}$ & Argon Arc & \\
\hline & & & & ANSI: C64445 & & \\
\hline & AMN-19 & $\begin{array}{l}0.5 \mathrm{Ci} \text { of } \\
{ }^{241} \mathrm{Am}\end{array}$ & $\begin{array}{l}\text { A mixture of }{ }^{241} \text { Am oxide powder and } \\
\text { beryllium powder that is pressed into }\end{array}$ & $\begin{array}{l}\text { Stainless steel not } \\
\text { specified }\end{array}$ & $\begin{array}{l}\text { Method not } \\
\text { specified }\end{array}$ & \\
\hline & $\begin{array}{l}\text { AMN-22 } \\
(4 / 78)\end{array}$ & $1.0 \mathrm{Ci}$ of ${ }^{24 !} \mathrm{Am}$ & $\begin{array}{l}\text { pellets and loaded into a stainless steel } \\
\text { cell }\end{array}$ & $22.4 \times 31 \mathrm{~mm}$ & & \\
\hline
\end{tabular}


Table B-1. (continued).

\begin{tabular}{|c|c|c|c|c|c|c|}
\hline $\begin{array}{c}\text { Manufacturer/ } \\
\text { distributor }\end{array}$ & $\begin{array}{c}\text { Model } \\
\text { (date evaluated) }\end{array}$ & Strength & Form & $\begin{array}{c}\text { Capsule } \\
\text { material/size }\end{array}$ & Welding & $\begin{array}{l}\text { Neutron } \\
\text { emission }\end{array}$ \\
\hline \multirow[t]{3}{*}{$\begin{array}{l}\text { Amersham Corporation } \\
2636 \text { S. Clearbrook Dr. } \\
\text { Arlington Heights, IL } \\
60005\end{array}$} & $\begin{array}{l}\text { AMN-CYn } \\
\text { (Series) } \\
(7 / 20 / 89)\end{array}$ & $\begin{array}{l}\mathrm{Up}_{\mathrm{p}} \text { to } 20 \mathrm{Ci} \text { of } \\
{ }^{241} \mathrm{Am}\end{array}$ & $\begin{array}{l}{ }^{211} \text { Am oxide is combined with } \\
\text { beryllium powders, and the mixture is } \\
\text { pressed }\left(10 \mathrm{~T} / \mathrm{in}^{2}\right) \text { into a pellet } \\
\text { [Oil well logging applications] } \\
\text { Pellets vary in size; the larger the } \\
\text { activity, the larger the pellet. }\end{array}$ & $\begin{array}{l}316 \text { stainless steel } \\
\text { inner capsule } \\
\text { Outer capsule: } \\
\text { Monel } \\
\text { K500 or 17-4 PH } \\
\text { or MP } 35 \text { H } \\
\text { ANSI Class } \\
\text { 77C55434 or } \\
\text { 77E66534 }\end{array}$ & TIG & $\begin{array}{l}18 \mathrm{rem} / \mathrm{hr} \\
\text { Neutron } \\
\text { dose at } 5 \mathrm{~cm} \\
\text { from } 20 \mathrm{Ci}\end{array}$ \\
\hline & $\begin{array}{l}\text { AMN-PEn } \\
\text { (Series) } \\
(3 / 12 / 87) \\
\text { (See Figure A-2) }\end{array}$ & $\begin{array}{l}\text { Up to } 20 \mathrm{Ci} \text { of } \\
{ }^{241} \mathrm{Am}\end{array}$ & $\begin{array}{l}{ }^{241} \mathrm{Am} \text { is mixed with beryllium } \\
\text { powders and the mixture is pressed } \\
\text { into a pellet. }\end{array}$ & $\begin{array}{l}316 \text { stainless steel } \\
\text { inner capsule } \\
316 \mathrm{~L} \text { or ARMCO } \\
17-4 \mathrm{PH} \text { steel } \\
5 \text { to } 36 \mathrm{~mm} \\
\text { diameter } \\
12 \text { to } 100 \mathrm{~mm} \text { length } \\
\text { Various ANSI } \\
\text { classifications }\end{array}$ & TIG & $\begin{array}{l}0.9 \mathrm{rem} / \mathrm{hr} \\
\text { at } 5 \mathrm{~cm} / \mathrm{Ci} \\
25 \mathrm{mrem} / \mathrm{hr} \\
\text { at } 30 \mathrm{~cm} / \mathrm{Ci}\end{array}$ \\
\hline & $\begin{array}{l}\text { VD,VD (HP) } \\
(10 / 17 / 88)\end{array}$ & $2 \mathrm{Ci}$ of ${ }^{241} \mathrm{Am}$ & Not specifically described & $\begin{array}{l}\text { Doubly encapsulated } \\
\text { in } 304 \text { or } 316 \\
\text { stainless steel } \\
\text { ANSI ratings of } \\
77 E 43333 \text { or } \\
77 E 56533\end{array}$ & & $\begin{array}{l}\text { (Unknown if } \\
\text { Am/Be } \\
\text { Source) }\end{array}$ \\
\hline $\begin{array}{l}\text { Monsanto Company } \\
\text { Dayton Engineered } \\
\text { Products } \\
\text { Station B. Box } 8 \\
1515 \text { Nicholas Road } \\
\text { Dayton, OH } 45407\end{array}$ & $\begin{array}{l}\text { 2722-BT (Series) } \\
(10 / 31 / 75)\end{array}$ & $0.95 \mathrm{Ci}$ of ${ }^{241} \mathrm{Am}$ & $\begin{array}{l}\text { Target material for the production of } \\
\text { neutron source consists of beryllium } \\
\text { metal powder }(0.4 \mathrm{~g}) \text { mixed with } \\
{ }^{241} \mathrm{Am} \text { oxide powder and pressed into } \\
\text { the inner, cylindrically shaped capsule. }\end{array}$ & $\begin{array}{l}304 \text { stainless steel } \\
\text { Inner: } 45 \text { mils thick } \\
\text { Outer: } 46 \text { mils thick } \\
0.5 \text { in. diameter } \\
0.950 \text { in. length }\end{array}$ & TIG & \\
\hline
\end{tabular}

ANSI 64525 
Table B-1. (continued).

\begin{tabular}{|c|c|c|c|c|c|c|}
\hline $\begin{array}{c}\text { Manufacturer/ } \\
\text { distributor }\end{array}$ & $\begin{array}{c}\text { Model } \\
\text { (date evaluated) } \\
\end{array}$ & Strength & Form & $\begin{array}{c}\text { Capsule } \\
\text { material/size }\end{array}$ & Welding & $\begin{array}{l}\text { Neutron } \\
\text { emission }\end{array}$ \\
\hline \multirow{14}{*}{$\begin{array}{l}\text { Monsanto Company } \\
\text { Dayton Engineered } \\
\text { Products } \\
\text { Station B. Box } 8 \\
1515 \text { Nicholas Road } \\
\text { Dayton, OH } 45407\end{array}$} & 24154-A & $\mathrm{Up}_{\mathrm{p}}$ to $1 \mathrm{Ci}^{241} \mathrm{Am}$ & An isotope of either ${ }^{211} \mathrm{Am}$ or ${ }^{238} \mathrm{Pu}$ in & & TIG & Varies \\
\hline & 24154-B & [also ${ }^{238} \mathrm{Pu}(1 \mathrm{Ci})$ & the form of an oxide is doubly & & & \\
\hline & 24154-C & $\begin{array}{l}\text { and } C f-252(1.1 \mathrm{mg}) \\
\text { in this }\end{array}$ & encapsulated in stainless steel with & & & \\
\hline & & configuration] & beryllium, lithium, boron, or calcium & & & \\
\hline & & & $\begin{array}{l}\text { fluoride to form a neutron source. } \\
\text { The capsules are sealed by TIG weld. }\end{array}$ & & & \\
\hline & & & $\begin{array}{l}\text { The isotope in the Model } 24154-\mathrm{A} \text { is } \\
\text { contained in an unsealed thin } \\
\text { aluminum tube inside the inner capsule } \\
\text { while no aluminum tube is used in the } \\
\text { Model } 24154-\mathrm{B} \text { and } 24154-\mathrm{C} \text {. }\end{array}$ & & & \\
\hline & . & & $\begin{array}{l}\text { Model } 24154 \mathrm{C} \text { qualifies as } \\
\text { ANSI } 77 \mathrm{C} 66544 .\end{array}$ & & & \\
\hline & $\begin{array}{l}2726-\mathrm{Bx} \\
(5 / 9 / 80)\end{array}$ & $\begin{array}{l}14 \mathrm{Ci} \text { of }{ }^{241} \mathrm{Am} \\
14 \mathrm{Ci} \text { of }{ }^{238} \mathrm{Pu}\end{array}$ & $\begin{array}{l}\text { A physical mixture of the isotope } \\
\text { powder and the target material (Be, } \\
\mathrm{Li}, \mathrm{B}, \text { or } \mathrm{F} \text { ) is compressed into the } \\
\text { inner capsule and the end cap is } \\
\text { welded into place. }\end{array}$ & $\begin{array}{l}304 \text { stainless steel; } \\
\text { ANSI 77E64525 }\end{array}$ & TIG & \\
\hline & $\begin{array}{l}\text { H } 245258 \text { (NSR- } \\
\text { M) } \\
(10 / 8 / 80)\end{array}$ & 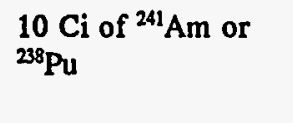 & $\begin{array}{l}\text { A mixture of isotope and target } \\
\text { material, beryllium powder, is } \\
\text { pelletized. }\end{array}$ & $\begin{array}{l}\text { Inner: } 304 \text { stainless } \\
\text { steel; extra space } \\
\text { taken up by metal }\end{array}$ & TIG & $\begin{array}{l}9-11 \mathrm{rem} / \mathrm{hr} \\
\text { at } 5 \mathrm{~cm}\end{array}$ \\
\hline & & & & shims & & $\begin{array}{l}250 \mathrm{~m} \\
\mathrm{rem} / \mathrm{hr}\end{array}$ \\
\hline & & & $"$ & $\begin{array}{l}\text { Outer: } 18 \% \text { nickel } \\
\text { maraging steel }\end{array}$ & & at $30 \mathrm{~cm}$ \\
\hline & $\begin{array}{l}24113 \\
(3 / 2 / 81) \\
\text { (See Figure A-3) }\end{array}$ & Varies & $\begin{array}{l}\text { Target material for the production of } \\
\text { neutron may consist of a powder of } \\
\text { beryllium metal; lithium hydroxide, } \\
\text { metal, or hydride; boron metal and }\end{array}$ & $\begin{array}{l}\text { Inner wall thickness: } \\
0.081 \text { in. of } 304 \\
\text { stainless steel }\end{array}$ & TIG & $\begin{array}{l}23 \mathrm{rem} / \mathrm{hr} \text { at } \\
5 \mathrm{~cm} \text { from } \\
16 \mathrm{Ci}\end{array}$ \\
\hline & & & $\begin{array}{l}\text { calcium fluoride. The source and } \\
\text { target powders are mixed and } \\
\text { compressed into the inner capsule. }\end{array}$ & $\begin{array}{l}\text { Outer wall } \\
\text { thickness: } 0.100 \text { in. } \\
\text { of } 17-4 \mathrm{PH}\end{array}$ & & $\begin{array}{l}4 \times 10^{7} \mathrm{n} / \mathrm{sec} \text {. } \\
\text { for } 16 \mathrm{Ci} \\
\text { source }\end{array}$ \\
\hline & & & bottom and a welded cap. & ANSI 77E66546 & & \\
\hline
\end{tabular}


Table B-1. (continued).

\begin{tabular}{|c|c|c|c|c|c|c|}
\hline $\begin{array}{l}\text { Manufacturer/ } \\
\text { distributor }\end{array}$ & $\begin{array}{c}\text { Model } \\
\text { (date evaluated) }\end{array}$ & Strength & Form & $\begin{array}{c}\text { Capsule } \\
\text { material/size }\end{array}$ & Welding & $\begin{array}{l}\text { Neutron } \\
\text { emission }\end{array}$ \\
\hline \multirow{10}{*}{$\begin{array}{l}\text { Monsanto Company } \\
\text { Dayton Engineered } \\
\text { Products } \\
\text { Station B. Box } 8 \\
1515 \text { Nicholas Road } \\
\text { Dayton, OH } 45407\end{array}$} & $\begin{array}{l}2720 A, B \text {, or } C \\
\text { Series } \\
(5 / 24 / 83)\end{array}$ & Up to $78 \mathrm{Ci}$ & $\begin{array}{l}\text { The source and production powders } \\
\text { are mixed and compressed into the } \\
\text { inner capsule. }\end{array}$ & $\begin{array}{l}\text { Dimensions vary } \\
\text { Meets ANSI } \\
\text { 68E64525 }\end{array}$ & & $\begin{array}{l}2.4 \times 10^{6} \\
\mathrm{n} / \mathrm{sec} / \mathrm{Ci}\end{array}$ \\
\hline & $\begin{array}{l}24181 \\
(8 / 19 / 82)\end{array}$ & $\begin{array}{l}{ }^{438} \mathrm{Ci} \text { of }{ }^{241} \mathrm{Am} \text { or } \\
{ }^{23 \mathrm{u}}\end{array}$ & $\begin{array}{l}\text { The source and target powders are } \\
\text { mixed and compressed into the inner } \\
\text { capsule. }\end{array}$ & $\begin{array}{l}\text { Meets ANSI } \\
\text { 77E66546 }\end{array}$ & & \\
\hline & $\begin{array}{l}24183 \\
(5 / 21 / 83)\end{array}$ & $\begin{array}{l}57 \mathrm{Ci} \text { of }{ }^{241} \mathrm{Am} \text { or } \\
57 \mathrm{Ci} \text { of }{ }^{238} \mathrm{Pu}\end{array}$ & Not described. & $\begin{array}{l}\text { Doubly encapsulated } \\
\text { neutron source }\end{array}$ & & \\
\hline & & & & $\begin{array}{l}\text { Inner capsule: } 304 \\
\text { stainless steel }\end{array}$ & & \\
\hline & & & & $\begin{array}{l}\text { Outer: } 17-4 \mathrm{PH} \text {, } \\
\text { solution annealed }\end{array}$ & & \\
\hline & & & & $\begin{array}{l}\text { Inner thickness: } \\
0.0705 \text { in. } \\
\text { Outer thickness: } \\
0.0605 \text { in. min. }\end{array}$ & & \\
\hline & $\begin{array}{l}24195 \\
(5 / 25 / 83)\end{array}$ & $\begin{array}{l}190 \mathrm{mCi} \text { of }{ }^{241} \mathrm{Am} \\
\text { or } 190 \mathrm{mCi} \text { of } \\
\mathrm{Pu}-23\end{array}$ & Not described. & Doubly encapsulated & TIG & \\
\hline & $\begin{array}{l}24194 \\
(1 / 18 / 83)\end{array}$ & $\begin{array}{l}340 \mathrm{mCi} \text { of }{ }^{241} \mathrm{Am} \\
\text { or }{ }^{238} \mathrm{Pu}\end{array}$ & Not described (custom source). & & & \\
\hline & $\begin{array}{l}24197 \\
(1 / 18 / 83)\end{array}$ & $\begin{array}{l}700 \mathrm{mCi} \text { of }{ }^{241} \mathrm{Am} \\
\text { or }{ }^{238} \mathrm{Pu}\end{array}$ & Not described (custom source). & & & \\
\hline & $\begin{array}{l}24107 \\
(10 / 5 / 84)\end{array}$ & $\begin{array}{l}4.5 \mathrm{Ci} \text { of }{ }^{241} \mathrm{Am} \\
\text { or }{ }^{238} \mathrm{Pu}\end{array}$ & $\begin{array}{l}\text { The mixture isotope in oxide form and } \\
\text { target material (B, Be, } \mathrm{Li} \text {, or } \mathrm{F}) \text { is } \\
\text { compacted into a pellet, and the pellet } \\
\text { is placed into the primary capsule } \\
\text { where the mixture of isotope and } \\
\text { target is compressed into the primary } \\
\text { capsule. }\end{array}$ & $\begin{array}{l}\text { Doubly encapsulated } \\
\text { ANSI } 68 \text { E4525 } 304 \\
\text { stainless steel } \\
\text { inner and outer } \\
\text { capsules }\end{array}$ & TIG & \\
\hline
\end{tabular}


Table B-1. (continued).

\begin{tabular}{|c|c|c|c|c|c|c|}
\hline $\begin{array}{l}\text { Manufacturer/ } \\
\text { distributor }\end{array}$ & $\begin{array}{c}\text { Model } \\
\text { (date evaluated) }\end{array}$ & Strength & Form & $\begin{array}{c}\text { Capsule } \\
\text { material/size }\end{array}$ & Welding & $\begin{array}{l}\text { Neutron } \\
\text { emission }\end{array}$ \\
\hline \multirow{5}{*}{$\begin{array}{l}\text { General Radioisotope } \\
\text { Products, Inc. } \\
\text { San Ramon, CA } 94583\end{array}$} & $\begin{array}{l}6082 \\
(6 / 20 / 74)\end{array}$ & Up to $500 \mathrm{mCi}$ & ${ }^{241}$ Am oxide/beryllium pressed pellets & & & \\
\hline & & & $\begin{array}{l}{ }^{241} \text { Am oxide/beryllium pressed and } \\
\text { sintered pellets }\end{array}$ & & & \\
\hline & & & $\begin{array}{l}\text { Cesium polyglass beads, pressed }{ }^{241} \mathrm{Am} \\
\text { oxide/beryllium pellets }\end{array}$ & & & ' \\
\hline & $\begin{array}{l}7022 \\
(9 / 30 / 74)\end{array}$ & $\begin{array}{l}\mathrm{Up} \text { to } 1000 \mathrm{mCi} \\
\text { of }{ }^{241} \mathrm{Am} \\
\text { or }{ }^{238} \mathrm{Pu}\end{array}$ & $\begin{array}{l}{ }^{241} \text { Am oxide/beryllium are in the form } \\
\text { of a pressed pellet. }\end{array}$ & 304 stainless steel & Heli Arc & \\
\hline & $\begin{array}{l}6002 \\
(2 / 6 / 76)\end{array}$ & $\begin{array}{l}\mathrm{Up}_{\mathrm{p}} \text { to } 100 \mathrm{mCi} \\
{ }^{241} \mathrm{Am}\end{array}$ & $\begin{array}{l}{ }^{241} \mathrm{Am} \text { oxide/beryllium in the form of } \\
\text { pressed pellets. }\end{array}$ & 304 stainless steel & Heli Arc & \\
\hline Amersham Corporation & $\mathrm{XN}-1$ & $40 \mathrm{Ci}$ & $\begin{array}{l}{ }^{241} \text { Am oxide + Lithium Hydroxide } \\
\text { (blended and pelletized) }\end{array}$ & & & \\
\hline $\begin{array}{l}\text { Atomic Energy of } \\
\text { Canada, Ltd. } \\
\text { Commerce Products } \\
\text { P.O. Box } 93 \\
\text { Ottawa, Canada }\end{array}$ & $\begin{array}{l}C-143 \\
(9 / 16 / 66)\end{array}$ & Unspecified & $\begin{array}{l}\text { Radium Beryllium } \\
\text { Unspecified }\end{array}$ & & & \\
\hline \multirow[t]{3}{*}{$\begin{array}{l}\text { Gamma Industries, Inc. } \\
\text { P.O. Box } 2543 \\
\text { Baton Rouge, LA } 70821\end{array}$} & $\begin{array}{l}\text { NB-S-5 } \\
\text { NB-S-20 } \\
(5 / 73)\end{array}$ & $\begin{array}{l}5 \mathrm{Ci} \\
20 \mathrm{Ci}\end{array}$ & ${ }^{241} \mathrm{Am}$ oxide mixed with beryllium & $\begin{array}{l}304 \text { to } 316 \text { stainless } \\
\text { steel } \\
\text { ANSI } 45515\end{array}$ & $\begin{array}{l}\text { TIG } \\
\text { (Heli Arc) }\end{array}$ & \\
\hline & $\begin{array}{l}128 \\
2184\end{array}$ & Unspecified & $\begin{array}{l}\text { Radioactive material is deposited in the } \\
\text { inner capsule as an } \\
\text { americium/beryllium pellet and cesium } \\
\text { chloride in an aluminum oxide binder. }\end{array}$ & & & \\
\hline & PL-Am Be-2.7 & $3 \mathrm{Ci}$ & $\begin{array}{l}\text { Americium- } 241 \text { oxide powder mixed } \\
\text { with beryllium powder and doubly } \\
\text { encapsulated in stainless steel. }\end{array}$ & & & \\
\hline
\end{tabular}


Table B-1. (continued).

\begin{tabular}{|c|c|c|c|c|c|c|}
\hline $\begin{array}{l}\text { Manufacturer/ } \\
\text { distributor }\end{array}$ & $\begin{array}{c}\text { Model } \\
\text { (date evaluated) }\end{array}$ & Strength & Form & $\begin{array}{c}\text { Capsule } \\
\text { material/size }\end{array}$ & Welding & $\begin{array}{l}\text { Neutron } \\
\text { emission }\end{array}$ \\
\hline \multirow[t]{4}{*}{$\begin{array}{l}\text { DuPont NEN } \\
\text { (formerly New England } \\
\text { Nuclear) } \\
601 \text { Treble Cove Road } \\
\text { North Billerica, MA } \\
01862\end{array}$} & $\begin{array}{l}\text { RNG.1 } \\
(5 / 1 / 71)\end{array}$ & $5 \mathrm{mCi}$ & $\begin{array}{l}\text { The } \mathrm{Ra}^{-\mathrm{Br}_{2}} \text { /beryllium mixture is } \\
\text { pelletized in an inner stainless steel } \\
\text { (type } 316 \mathrm{~L} \text { ) capsule. This inner } \\
\text { capsule is then placed within a second } \\
\text { stainless steel capsule. }\end{array}$ & & Heli Arc & \\
\hline & $\begin{array}{l}\text { NER-550 } \\
(12 / 23 / 71)\end{array}$ & $1 \mathrm{Ci}$ of ${ }^{24 !} \mathrm{Am}$ & $\begin{array}{l}\text { The source consists of americium } \\
\text { oxide and beryllium powder } \\
\text { compressed (until pelletized) into a } \\
\text { depression (cup) in the innermost } \\
\text { source component, which is press- } \\
\text { fitted into the outer shell of the inner } \\
\text { source capsule. The inner capsule is } \\
\text { then press-fitted into the outer capsule } \\
\text { followed by the outer capsule plug, } \\
\text { which is press-fitted into place and } \\
\text { seal welded to the outer capsule. }\end{array}$ & $\begin{array}{l}\text { Doubly encapsulated } \\
\text { as above; } \\
316 \text { stainless steel; } \\
\text { Meets ANSI N5110- } \\
1968 \text { as C- or E- } \\
54434\end{array}$ & & \\
\hline & $\begin{array}{l}\text { NER-560 } \\
(12 / 30 / 71)\end{array}$ & $\begin{array}{l}1 \mathrm{Ci} \text { of }{ }^{241} \mathrm{Am} \text { and } \\
200 \mathrm{mCi} \text { of }{ }^{137} \mathrm{Cs}\end{array}$ & $\begin{array}{l}\text { Same as NER-550 except a } 30-\mathrm{mm}- \\
\text { thick wafer of glass fiber containing } \\
{ }^{137} \mathrm{Cs} \text { is placed over the Am-Be pellet. } \\
\text { This combination is press-fitted into } \\
\text { the outer shell of the inner source } \\
\text { capsule. }\end{array}$ & $\begin{array}{l}\text { Doubly encapsulated } \\
\text { as stated previously; } \\
316 \text { stainless steel; } \\
\text { Meets ANSI } 5110 \text { - } \\
19668 \text { as C- or } \\
\text { E-54434 }\end{array}$ & & \\
\hline & NER-560-A & $\begin{array}{l}1 \mathrm{Ci} \text { of }{ }^{241} \mathrm{Am} \text { and } \\
200 \mathrm{mCi} \text { of }{ }^{137} \mathrm{Cs}\end{array}$ & $\begin{array}{l}\text { Same as Model NER- } 560 \text {. } \\
\text { Modification is due to handling rods. }\end{array}$ & & & \\
\hline
\end{tabular}

